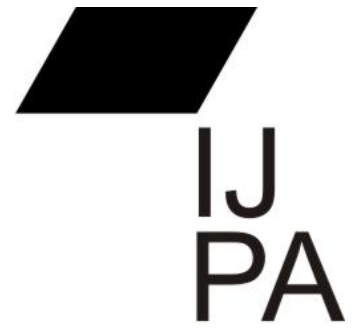

ISSN $2460-0369$

\title{
MENDOBRAK KETERBATASAN MASYARAKAT: MEWUJUDKAN DESA OPEN DEFECATE FREE DI KABUPATEN BANYUWANGI MELALUI INOVASI "PUJASERA"
}

Tatiek Setyaningsih

Insiator Program Pujasera dan

Kepala UPTD Puskesmas Tampo Banyuwangi tatieksetya@gmail.com

\section{Bayu Mitra Adhyatma Kusuma}

Dosen Universitas Islam Negeri (UIN) Sunan Kalijaga

Yogyakarta dan Pemerhati Kebijakan Publik

bayumitraa.kusuma@yahoo.com

\begin{abstract}
ABSTRAK
Pada tahun 2013, dari 217 desa di Banyuwangi telah terdapat 27 desa ODF. Namun tak satupun desa ODF tersebut berada di wilayah kerja Puskesmas Tampo yang secara geografis dibentangi oleh sungai besar dan sempalan-sempan kecil. Kondisi tersebut sangat mendukung kebiasaan masyarakat buang air besar di sungai. Untuk mengatasi permasalahan tersebut muncullah program "Pergunakan Jamban Sehat, Rakyat Aman" atau "Pujasera". Hasil penelitian menunjukan bahwa program Pujasera dilaksanakan dengan memberdayakan masyarakat meliputi pembentukan kader Pujasera, satgas ODF, dan komunitas arisan jamban sehat. Mereka bahu-membahu dalam bergotong royong membangun jamban sehat, kampanye ODF, dan menyelenggarakan klinik sanitasi melalui kemitraan dengan PNPM mandiri pedesaan, toko bangunan, serta media cetak dan elektronik sebagai partner sosialisasi. Output dari inovasi Pujasera adalah terjadinya perubahan perilaku masyarakat dari buang air besar di sungai beralih ke jamban sehat, menurunnya angka kesakitan akibat lingkungan buruk dari 35\% menjadi 18\%, kemudahan masyarakat miskin dalam mendapatkan jamban sehat, serta pola kehidupan sosial masyarakat yang lebih beradab dan bermartabat.
\end{abstract}

Kata Kunci: Kemiskinan, Inovasi, Pujasera, Open

Defecate Free 
LATAR BELAKANG

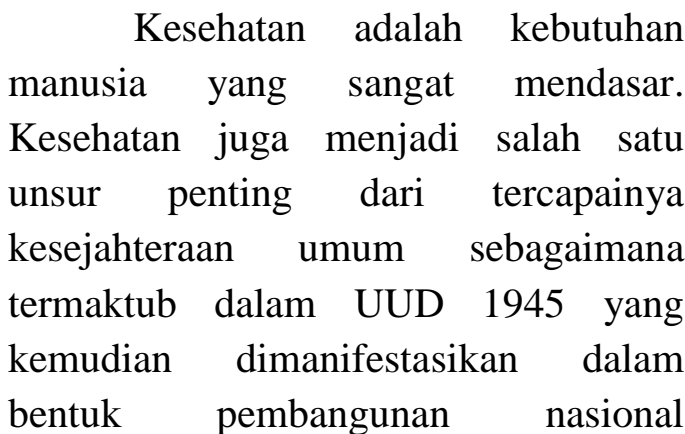
berkelanjutan. Ini juga selaras dengan poin ketiga dalam Sustainable Development Goals yang dicetuskan oleh United Nations Development Program (UNDP) yaitu memastikan hidup sehat dan mempromosikan kesejahteraan untuk semua di segala usia (Osborn et al., 2015:6). Konsep ini merupakan kelanjutan dari program Millenium Development Goals yang telah berjalan sebelumnya (UNDESA, 2007:7). Namun proses pembangunan nasional khususnya di sektor kesehatan ternyata mengalami berbagai hambatan, baik hambatan yang berasal dari keterbatasan negara maupun keterbatasan masyarakat. Terkait dengan keterbatasan masyarakat, salah satu hal yang paling mendasar adalah rendahnya kesadaran masyarakat terutama di wilayah pedesaan akan pentingnya lingkungan yang bersih dan sehat. Kurangnya kesadaran tersebut dapat dilihat secara nyata dari kebiasaan masyarakat pedesaan buang air besar di daerah aliran sungai. Seperti kawasan pedesaan di Kabupaten Banyuwangi, Jawa Timur yang juga tak luput dari permasalahan klasik ini.
Pada tahun 2013 terdapat 27 desa berstatus Open Defecate Free (ODF) dari jumlah total 217 desa di Kabupaten Banyuwangi (Pemkab Banyuwangi, 2013). Namun ironisnya tak satupun desa ODF tersebut yang berada di wilayah kerja Puskesmas Tampo. Bila diidentifikasikan secara lebih terperinci, ada beberapa faktor yang menjadi penyebab mengapa tak satupun desa di wilayah kerja Puskesmas Tampo menyandang predikat ODF. Pertama, secara geografis wilayah kerja Puskesmas Tampo dibentangi oleh sungai besar dan sempalan-sempalan kecil yang sangat mendukung kebiasaan masyarakat untuk buang air besar di sembarang tempat khususnya sungai. Kondisi tersebut membuat masyarakat mengambil sisi praktis saja dengan berak di sungai dan persawahan. Terlebih banyak warga yang tinggal di bantaran sungai beraktivitas setiap hari dengan membuang sampah, mencuci, bahkan mandi di sungai tersebut. Akibatnya lingkungan tercemari limbah organik berupa feses manusia dan juga limbah anorganik dari sampah rumah tangga lainnya yang juga dibuang di sungai tersebut.

Kedua, kemiskinan yang menyebabkan ketidakmampuan warga masyarakat untuk memiliki jamban sehat dan layak. Ketiga, pendidikan yang relatif rendah menyebabkan tingkat kesadaran masyarakat akan pentingnya hidup sehat juga berbanding lurus. Kombinasi dari tiga faktor 
tersebut kemudian membentuk pola pikir masyarakat secara turun-temurun yang tidak peduli akan perlunya sanitasi yang baik. Data dari Puskesmas Tampo menunjukkan bahwa angka kesakitan yang disebabkan oleh sanitasi buruk sangat tinggi antara lain: diare 28,2\%, thypoid $8,7 \%$, penyakit kulit $12 \%$, demam berdarah $0,25 \%$, dan influenza $10,3 \%$. Tragis, diare telah menyebabkan dua kasus meninggal. Yang juga tak kalah mengejutkan adalah terjadi satu kasus busung lapar di wilayah kerja Puskesmas Tampo. Namun upaya penanganan secara terintegrasi terhadap penyakit-penyakit yang disebabkan karena faktor lingkungan buruk tersebut belum mampu dilakukan secara efektif. Kondisi ini disebabkan belum tersedianya tenaga ahli kesehatan lingkungan (sanitarian) dan klinik sanitasi. Minimnya tenaga sanitarian adalah dampak dari belum adanya pelatihan dari Dinas Kesehatan Kabupaten Banyuwangi sehingga program sanitasi lingkungan di wilayah kerja Puskesmas Tampo dikelola oleh tenaga seadanya.

Oleh karena itu dibutuhkan suatu terobosan yang mampu menangani permasalahan-permasalahan lingkungan di atas secara komprehensif. Ini mengingat keberhasilan pembangunan nasional khususnya di sektor kesehatan sangat dipengaruhi oleh ketersediaan sumber daya manusia yang sehat, terampil, dan ahli serta disusun dalam suatu program kesehatan dengan perencanaan terpadu yang didukung oleh data dan informasi epidemiologi yang valid (Departemen Kesehatan RI, 2005). Sebagai langkah konkret dalam upaya mewujudkan desa ODF di wilayah kerjanya, Puskesmas Tampo menginisiasi sebuah inovasi kebijakan yang dimanifestasikan dalam program bertajuk "Pergunakan Jamban Sehat, Rakyat Aman" atau disebut dengan "Pujasera". Program Pujasera bertujuan untuk memberikan pelayanan bantuan kepada masyarakat untuk mendapatkan sanitasi yang bersih khususnya jamban yang layak dan sehat. Fungsi pelayanan publik saat ini memang masih menjadi isu yang sangat strategis karena perbaikan pelayanan publik di Indonesia masih cenderung stagnan. Sedangkan implikasi dari fungsi pelayanan sangatlah luas dalam kehidupan ekonomi, politik, ataupun sosial budaya (Kusuma dan Octastefani, 2015:104).

Pelayanan masyarakat dalam mendapatkan standar sanitasi yang lebih baik melalui program Pujasera bukanlah tanpa hambatan dan tantangan. Banyak kendala yang harus dihadapi dan disiasati dalam upaya mewujudkan desa ODF di wilayah kerja Puskesmas Tampo melalui program ini. Namun faktanya program ini mampu menembus 50 besar kompetisi inovasi pelayanan publik (SiNovik) 2015 yang diselenggarakan oleh Kementerian Pendayagunaan Aparatur Negara dan Reformasi Birokrasi Republik Indonesia dan menjadi salah satu kandidat kuat 
program yang akan diajukan ke United Nations Public Service Awards (UNPSA). Oleh karena itu penulis berketetapan untuk mendeskripsikan dan menganalisa secara lebih komprehensif proses penerapan program Pujasera dalam mendobrak keterbatasan masyarakat untuk mewujudkan desa berstatus ODF di Kabupaten Banyuwangi pada umumnya dan di wilayah kerja Puskesmas Tampo pada khususnya.

\section{KAJIAN TEORI}

\section{Kemiskinan}

Kemiskinan hingga saat ini masih menjadi masalah klasik di negara-negara berkembang. Menurut Peraturan Presiden RI No. 7 Tahun 2005 tentang Rencana Pembangunan Jangka Menengah Nasional, kemiskinan adalah ketika seseorang atau sekelompok orang, baik laki-laki dan perempuan, tidak terpenuhi hak-hak dasarnya untuk mempertahankan dan mengembangkan kehidupan yang bermartabat. Kondisi ini muncul saat mereka tidak mampu memenuhi kebutuhan dasar mereka seperti pangan, papan, dan sandang. Mereka hidup di bawah tingkat pendapatan riil minimum tertentu atau dibawah garis kemiskinan internasional (Todaro dan Smith, 2003:7). Batas garis kemiskinan internasional tersebut secara umum diukur dari penghasilan penduduk yang berada pada angka kurang dari US\$ 1 per hari. Pemerintah pusat maupun daerah secara pro-aktif terus menekan angka kemiskinan. Meski faktanya mengurangi angka kemiskinan tidaklah semudah membalikkan telapak tangan sehingga kemiskinan masih terus eksis sampai saat ini.

Kemiskinan dapat disebabkan oleh berbagai faktor baik yang berasal dari internal maupun eksternal. Latar belakang pendidikan yang rendah dan minimnya lapangan kerja merupakan faktor utama penyumbang tingginya tingkat kemiskinan di Indonesia. Kemiskinan bukan hanya yang bersifat absolut melainkan juga kultural. Ini jika kita mengacu pada persoalan sikap seseorang atau masyarakat yang disebabkan oleh faktor budaya, seperti tidak mau berusaha memperbaiki tingkat kehidupan, malas, pemboros, tidak kreatif meskipun ada bantuan dari pihak luar (Suryawati:2005). Pengukuran tentang tingkat kemiskinan di Indonesia pun sangat bervariasi. Munculnya banyak variasi ahsil survey tingkat kemiskinan tersebut tergantung dari kepentingan politik maupun ekonomi dari pihak yang berkepentingan. Atau jumlah golongan miskin dalam data dapat dikurangi dan ditambah sesuai dengan keinginan dan kepentingan pemangku kekuasaan untuk menciptakan kebijakan yang populis di mata masyarakat. Namun bagaimanapun juga kemiskinan bukanlah suatu hal yang tak mungkin diatasi. Kemiskinan juga bukanlah suatu masalah yang tanpa celah. Kemiskinan 
dapat didobrak dan diatasi dengan adanya kebijakan-kebijakan publik yang kreatif dan inovatif. Sebagaimana arisan jamban sehat dalam program Pujasera yang mampu mendobrak keterbatasan masyarakat miskin untuk mendapatkan jamban sehat.

\section{Kebijakan Publik}

Ada bias dan kerancuan dalam menerjemahkan public policy. Istilah public policy diterjemahkan oleh berbagai kalangan sesuai dengan kepentingan dan fokus yang diinginkan. Contohnya Jurusan Ilmu Pemerintahan menterjemahkan sebagai "kebijakan pemerintah", Jurusan Administrasi Publik menterjemahkan sebagai "kebijakan publik", dan Juruan Administrasi Bisnis akan menerjemahkan sebagai "kebijakan perusahaan" (Tangkilisan, 2003:6). Padahal kata public disini semestinya diterjemahkan sebagai segala sesuatu yang dilakukan ataupun tidak dilakukan oleh pemerintah selaku pemegang otoritas. Seperti yang dikemukakan oleh Thomas R. Dye yang merumuskan kebijakan publik sebagai semua pilihan atau tindakan yang dilakukan oleh pemerintah (Wahab, 2008:51). Selanjutnya Dunn (2006:65) juga mengemukakan bahwa kebijakan publik atau public policy adalah rangkaian panjang pilihan-pilihan yang kurang lebih berhubungan, termasuk keputusan untuk tidak berbuat, yang dibuat oleh kantor-kantor atau badan-badan pemerintah.

Pilihan dan tindakan yang dilakukan oleh pemerintah dalam pengertian ini bukan dilakukan secara sepihak, melainkan dengan memperhatikan kepentingan publik. Hal ini karena permasalahan publik sangatlah luas dan mencakup interaksi dari berbagai stakeholder seperti pemerintah, swasta, maupun masyarakat. Pada posisi inilah pemerintah sebagai pemegang otoritas menjadi pembuat kebijakan yang sangat menentukan. Salah satu hasil yang diharapkan dari sebuah proses kebijakan publik adalah untuk menghasilkan suatu program layanan guna memenuhi kebutuhan masyarakat. Sebagaimana diadaptasikan dari pendapat Nugroho (2014:25) bahwa pelayanan publik adalah agenda yang menjadi jembatan antara kebijakan publik dengan kehidupan publik. Dalam konteks program Pujasera, Pemerintah Kabupaten Banyuwangi melalui UPTD Puskesmas Tampo bukanlah menginisiasi program Pujasera untuk kepentingan mereka sendiri, melainkan mengutamakan pelayanan atas kebutuhan riil masyarakat di wilayah kerja Puskesmas Tampo.

\section{Inovasi Pelayanan Publik}

Secara umum pengertian pelayanan publik adalah suatu usaha yang dilakukan oleh seseorang atau kelompok orang atau instansi tertentu 
yang memberikan kemudahan kepada masyarakat dalam rangka pencapaian tujuan tertentu (Thoha, 2012:12). Ketika suatu pelayanan didefinisikan sebagai pelayanan publik maka tanggungjawab penyediaannya menjadi tanggungjawab negara (Dwiyanto, 2010:24). Meski pada pelaksanaannya negara tidak harus selalu melakukan semuanya sendiri. Negara dapat melibatkan lembaga non pemerintah lainnya dalam menyediakan pelayanan publik. Jika mengacu definisi dari Keputusan Menteri Pendayagunaan Aparatur Negara No. 63 Tahun 2003, pelayanan publik dapat dapat didefinisikan sebagai segala bentuk jasa pelayanan, baik dalam bentuk barang publik maupun jasa publik yang pada prinsipnya menjadi tanggungjawab dan dilaksanakan oleh instansi pemerintah di pusat, daerah, dan di lingkungan BUMN atau BUMD (Ratminto dan Winarsih, 2006:5).

Saat ini pelayanan publik tidak hanya dimonopoli oleh pemerintah pusat, melainkan telah terdesentralisasi seiring dengan berlakunya otonomi daerah di Indonesia sejak tahun 1999. Tujuan dari desentralisasi pelayanan publik adalah save money atau menghemat anggaran (Common et al., 1993:51). Pelayanan publik harus efektif dan daerah dianggap sebagai unsur pemerintah yang paling memahami kebutuhan masyarakat di lapangan. Namun fakta di lapangan memang menunjukkan bahwa peningkatan kualitas pelayanan publik di Indonesia berjalan dengan cukup lambat. Said (2012:40) mengemukakan bahwa secara internasional, reputasi birokrasi kita buruk. Banyak korupsi, tidak jelas tataran standarnya, tidak efisien, terlalu lemah dalam sistem pelayanan yang kaku dan jauh dari modern, tergantung dari orang seorang. Aturan terserah orangnya, bukan orangnya terserah aturan

Oleh karena itu dibutuhkan inovasi-inovasi yang mampu menjadi titik tolak meningkatnya kualitas pelayanan publik. Inovasi pelayanan publik dikatakan sebagai inisiatif terobosan dari instansi atau lembaga publik dalam upaya meningkatkan kualitas pelayanan publik. Inisiatif terobosan tersebut terletak pada kebaruan (novelty). Prinsip kebaruan tersebut dibedakan dengan inovasi dalam teknologi yang merupakan keunikan yang khas berbeda dengan yang lain (Imanuddin, 2016). Deskripsi di atas kemudian menjadi tonggak kemunculan serta penerapan program Pujasera. Program Pujasera adalah program pelayanan publik yang diinisisasi oleh Puskesmas Tampo selaku kepanjangan tangan dari Pemerintah Kabupaten Banyuwangi dan Dinas Kesehatan Kabupaten Banyuwangi. Dalam pelaksanaannya program Pujasera juga menggandeng stakeholder di luar pemerintahan yang secara lebih detail akan dibahas di bagian pembahasan. 


\section{METODE PENELITIAN}

Jenis penelitian dalam penelitian ini adalah kualitatif. Riset kualitatif merupakan suatu penelitian mendalam (in-depth), berorientasi pada kasus dari sejumlah kasus, termasuk satu stusi kasus (William dan Monge, 2001:293). Penelitian ini dilakukan dengan aksi partisipatif (participatory action research), yaitu penelitian yang melibatkan secara aktif semua pihakpihak yang relevan dalam mengkaji tindakan yang sedang berlangsung dalam rangka melakukan perubahan dan perbaikan ke arah yang lebih baik (Affandi et al., 2014:91). Lokus dari penelitian ini adalah Puskesmas Tampo, Desa Kaliploso, dan Desa Plampangrejo yang terletak di Kecamatan Cluring, Kabupaten Banyuwangi, jawa Timur. Adapun fokus dari penelitian ini adalah pendekatan strategis, pelaksanaan dan penerapan, output yang dihasilkan, kendala-kendala yang dihadapi, serta dampak dan keberlanjutan dari program Pujasera yang dicanangkan oleh Puskesmas Tampo.

\section{HASIL DAN PEMBAHASAN}

\section{Pendekatan Strategis}

Munculnya inovasi program Pujasera bermula dari lokakarya lintas sektoral yang diinisiasi oleh Kepala Puskesmas Tampo. Lokakarya lintas sektor tersebut diikuti oleh seluruh staf Pusksmas tampo serta perwakilan dari Dinas Kesehatan, Dinas Pekerjaan
Umum (PU) Pengairan, Kecamatan Cluring, UPTD Pendidikan Cluring, PNPM Mandiri, Desa di wilayah kerja Puskesmas Tampo, tokoh agama, toko bangunan, dan stakeholder terkait lainnya. Setelah melakukan pertemuan dan diskusi yang intensif, muncullah suatu terobosan inovasi yang diberi nama "Pergunakan Jamban Sehat, Rakyat Aman" atau disingkat dengan akronim "Pujasera". Pujasera adalah suatu gerakan bersama dengan mengoptimalkan peran masyarakat yang bertujuan untuk merubah perilaku masyarakat yang masih berak di sembarangan tempat. Untuk mempercepat informasi program Pujasera sampai ke masyarakat, selanjutnya dilakukan sosialisasi dengan menggandeng media cetak Radar Banyuwangi dan media elektronik Radio Airlangga FM. Selain itu publikasi juga dilakukan melalui banner dan leaflet yang dipasang ditempat umum dan dibagikan ke masyarakat .

Agar program berjalan efektif, selanjutnya dibentuk beberapa tim atau satuan tugas. Pertama, Kader Pujasera yang terdiri siswa relawan, Pramuka Saka Bhakti Husada, tokoh masyarakat dan kalangan pemuda sebagai pendamping dalam proses pembuatan jamban sehat. Kedua, membentuk satgas ODF di masing-masing dusun yang terdiri dari tokoh masyarakat, tokoh agama dan satgas "jeruk" sebagai pengawas keberhasilan dan keberlanjutan program Pujasera. Ketiga, 
membangun kemitraan dengan PNPM Mandiri Pedesaan dan toko bangunan sebagai pemberi pinjaman lunak dan penyedia bahan pembuatan jamban sehat. Keempat, membentuk 12 kelompok arisan jamban sehat di masing-masing dusun yang dilaksanakan setiap satu bulan sekali dengan anggota semua warga yang belum memiliki jamban dan dipimpin oleh Kepala Dusun.

Untuk lebih mendekatkan program Pujasera kepada masyarakat, kader Pujasera melakukanlah kampanye ODF dengan arak-arakan membawa banner, mengelilingi jalan desa dan sungai bersama instansi terkait. Dalam melaksanakan kampanye ODF, Tim Pujasera melibatkan seluruh stakeholder. Mereka kompak berkumpul di Balai Desa Kaliploso setiap hari Jumat jam 06.00 pagi. Kemudian secara serentak dipimpin oleh Kepala Desa melakukan arak-arakan dengan berjalan sepanjang jalan di bantaran sungai dengan membawa banner-banner yang berisikan ajakan untuk perilaku hidup bersih dan sehat. Kegiatan ini dilanjutkan dengan membongkar tempat-tempat buang air besar di sungai dan menancapkan banner-banner persuasif yang dibawa dalam arakarakan tersebut di tempat-tempat strategis. Tidak lupa setiap hari sabtu secara bergantian kader Pujasera bersama karyawan Puskesmas Tampo mengadakan siaran talkshow di radio Airlangga dengan pembahasan seputar program Pujasera. Lebih dari itu, program Pujasera juga menyediakan Klinik sanitasi untuk memberikan pelayanan dan konseling tentang kesehatan lingkungan, mengadakan gotong royong dalam pembuatan jamban sehat, serta mengoptimalkan tenaga perawat yang dikonversi menjadi sanitarian.

\section{Strategi Pelaksanaan dan Penerapan}

Sebuah program pasti dirancang dengan sedetail dan sebaik mungkin. Namun sebaik apapun sebuah program pasti membutuhkan strategi cerdik dalam pelaksanaannya. Strategi dibutuhkan dalam memecahkan setiap masalah yang muncul. Ada beberapa strategi yang dilakukan dalam penerapan inovasi Pujasera. Pertama, secara hukum program ini dilegalkan dengan SK Kepala Puskesmas Tampo No. 440/40/429.114.29/2014 yang di dalamnya melibatkan perwakilan dari SMK Kesehatan Visi Global, SMK Rhoudlotul, Pramuka Saka Bhakti Husada, tokoh masyarakat dan kalangan pemuda setempat. Kedua, menyusun standar operasional prosedur (SOP) program Pujasera untuk memastikan semuanya berjalan sesuai prosedur dan menjamin keberhasilannya. Ketiga, mengirim tenaga perawat untuk mengikuti pelatihan sanitarian di Dinas Kesehatan Banyuwangi agar menjadi tenaga sanitarian yang profesional dalam mengelola semua program kesehatan lingkungan dengan hasil yang optimal. Keempat, penandatanganan 
memorandum of understanding (MoU) antara Kepala Puskesmas Tampo dengan Radar Banyuwangi dan Radio Airlangga guna mensosialisasikan semua kegiatan Pujasera. Kelima. membuat banner yang isinya tentang slogan dan ajakan kepada masyarakat untuk berperilaku hidup sehat dan membagikan leaflet yang berisi berbagai informasi tentang Pujasera seperti tujuan Pujasera, apa saja rencana strategis, siapa saja kelompok sasaran dari program ini, siapa saja pemangku yang terlibat dari program Pujasera ini. Keenam, Tim Pujasera mengadakan pelatihan kader di Puskesmas Tampo dengan materi kesehatan lingkungan, cara pembuatan jamban sehat, kriteria jamban sehat, akibat buang air besar di sembarang tempat, dan teknik penyuluhan untuk merubah pola pikir masyarakat.

Adapun strategi yang ketujuh adalah penandatanganan MoU dengan UPTD Pendidikan Kecamatan Cluring tentang pembentukan kader Pujasera di sekolah-sekolah, konseling, dan pembagian leaflet. Kedelapan, Kepala Desa mengumpulkan Satgas ODF untuk diberikan pembekalan teknik pengawasan perilaku hidup bersih dan sehat kepada masyarakat. Kesembilan, penandatanganan MoU antara tim Pujasera dengan PNPM Mandiri Pedesaan dan toko-toko bangunan untuk pemberian pinjaman lunak dana dan material pembuatan jamban sehat kepada masyarakat miskin sebesar Rp. 1.200.000 per jamban. Mekanisme pinjaman lunak tersebut adalah sebelum dana dicairkan bahan pembuatan jamban disediakan oleh toko bangunan yang ditunjuk. Kemudian jika jamban telah selesai dibangun selanjutnya dilaporkan kepada PNPM Mandiri Pedesaan untuk dilakukan visitasi sebagai tindak lanjut dari pencairan dana. Kegiatan arisan jamban ini dilakukan secara rutin setiap bulan terbagi dalam 12 kelompok dimana setiap kelompok terdiri 30 anggota dengan satu kali setoran sebesar $\mathrm{Rp}$ 40.000, sehingga penerimaan arisan mendapatkan kucuran dana sebesar Rp. 1.200.000. Dan terakhir, mengoptimalkan kegiatan klinik sanitasi dengan menerima rujukan dari BP/KIA/Gizi untuk mendapatkan konseling berkaitan dengan penyakit yang disebabkan oleh sanitasi tak sehat.

\section{Output dan Kendala}

Beberapa output yang dihasilkan dari program Pujasera adalah: Pertama, terwujudnya dua desa (Kaliploso dan Plampangrejo) ODF dari empat desa yang ada di wilayah Puskesmas Tampo. Target tahun 2016, empat desa di wilayah puskesmas tampo sudah ODF seluruhnya. Kedua, meningkatnya kepemilikan jamban sehat. Data menjukkan bahwa dari $8.045 \mathrm{KK}$, kepemilikan jamban meningkat dari $1.034 \mathrm{KK}$ menjadi 5.025 KK. Dengan adanya arisan jamban, rata-rata setiap bulannya ada 288 jamban dibangun di wilayah Puskesmas Tampo 
(www.regional.kompas.com). Ketiga, adanya klinik sanitasi yang disediakan oleh Puskesmas melalui SK Kepala Puskesmas Tampo No. 440.01/40/429.114.29/2014 tentang pemberantasan penyakit lingkungan melalui upaya promotif dan preventif yang dilakukan secara terpadu, terarah tersusun secara terus-menerus. Keempat, menurunnya angka kesakitan atau morbiditas yang disebabkan oleh lingkungan buruk, secara keseluruhan dari $35 \%$ menjadi $18 \%$. Misalnya diare dari $28,2 \%$ menjadi $12 \%$, typiod dari $8,7 \%$ menjadi $3,8 \%$, DHF dari $0,25 \%$ menjadi $0,10 \%$, influenza dari $10,3 \%$ menjadi $8,5 \%$.

Dalam menghasilkan outputoutput yang telah disebutkan di atas, Tim Pujasera harus menyiasati beberapa kendala yang muncul. Beberapa kendala tersebut antara lain adalah: pertama, kendala waktu. Pemicuan tidak dapat dilaksanakan pada siang hari, karena melibatkan beberapa pemangku program inovasi dari berbagai SKPD dan tokoh masyarakat yang sering bersamaan kegiatannya. Selain itu sebagian besar masyarakat pada siang hari rata-rata bekerja sebagai petani, sehingga harus dilaksanakan di luar jam kerja (malam hari). Kedua, kendala sumber daya manusia. Tidak adanya tenaga sanitasi sehingga harus mengoptimalkan tenaga perawat. Upaya mengatasi kendala ini dilakukan dengan mengirim SDM perawat ke Dinas Kesehatan untuk mengikuti pelatihan tentang kesehatan lingkungan yang meliputi pemberdayaan masyarakat, lima pilar STBM, teknik pembuatan jamban sehat, teknik pengelolaan sampah yang benar, teknik pengolahan makanan dan kantin sehat, juga pengelolaan air bersih dan teknik pemberian penyuluhan. Ketiga, kendala kultural. Masyarakat sulit meninggalkan kebiasaan buang air besar di sungai karena faktor kebiasaan dan budaya walaupun sudah memiliki jamban. Untuk itu perlu pendekatan persuasif dengan mencontohkan beberapa dampak yang riil. Keempat, kendala ekonomi Kemiskinan menciptakan stigma masyarakat bahwa inovasi harus berupa bantuan. Solusi konkrit kendala ini dilakukan melalui pinjaman lunak dana dari PNPM Mandiri Pedesaan dan arisan jamban. Kelima, kendala psikologis. Adanya keraguan akan keberhasilan inovasi Pujasera dari pemangku program yang terlibat sehingga untuk lebih memantapkan kepada masyarakat bahwa program ini dapat betul-betul berhasil maka diadakan kampanye ODF dan pemasangan banner di tempat yang strategis sebelum deklarasi dilaksanakan. Terakhir adalah kendala sarana dan prasarana. Pada awalnya cakupan kunjungan kesehatan lingkungan sangat rendah karena belum adanya klinik sanitasi di Puskesmas Tampo. Untuk itu melalui program inovasi Pujasera ini Puskesmas Tampo menyediakan sebuah ruangan untuk Klinik Sanitasi terintegrasi. Klinik sanitasi bukan sebagai unit pelayanan 
yang berdiri sendiri, tetapi sebagai bagian terintegrasi dari Puskesmas, bekerjasama dengan program yang lain dari sektor terkait.

\section{Manfaat Nyata dan Pembelajaran}

\section{Program Pujasera telah} memberikan manfaat nyata bagi masyarakat di wilayah kerja Puskesmas Tampo dalam pelayanan penyediaan jamban sehat. Manfaat-manfaat tersebut antara lain adalah: Pada aspek kultural, terjadinya perubahan perilaku masyarakat dari kebiasaan buang air besar di sembarang tempat beralih ke jamban sehat. Perubahan ini terjadi karena masyarakat telah membuktikan adanya dampak positif pada terobosan inovasi Puajsera dengan segala strategi dan pelaksanaannya. Evaluasi terus dilakukan dengan mengawasi kebiasaan perilaku masyarakat sehari-hari oleh satgas ODF. Hal ini ditujukan agar masyarakat tidak kembali lagi pada kebiasaan buruk semula untuk buang air besar di sungai atau sembarang tempat lainnya. Di aspek kesehatan, meningkatnya kesehatan masyarakat yang dibuktikan dengan menurunnya angka kesakitan yang ditimbulkan oleh lingkungan buruk dihitung dari jumlah seluruh kunjungan. Meliputi diare dari $28,2 \%$ menjadi $14 \%$, thypoid dari $8,7 \%$ menjadi $3,8 \%$, DHF $0,25 \%$ menjadi $0,10 \%$, influeza dari $10,3 \%$ menjadi $8,5 \%$. Evaluasi dapat dilakukan melalui controlling data kunjungan klinik sanitasi. Tujuannya adalah angka kesakitan dapat terus ditekan dari waktu ke waktu.

Untuk manfaat dalam aspek ekonomi, masyarakat miskin dapat lebih mudah memiliki jamban sehat tanpa adanya prosedur yang rumit. Biaya tersebut didapatkan melalui pinjaman lunak dari PNPM Mandiri Pedesaan dan arisan jamban sehat. Evaluasi dilakukan dengan mengukur kemudahan dalam proses administrasi pencairan dana. Pada aspek sarana dan prasarana, pelayanan kesehatan di puskesmas menjadi lebih optimal dengan adanya klinik sanitasi. Penyakit yang disebabkan oleh buruknya lingkungan dapat ditangani secara paripurna oleh petugas sanitarian. Meningkatnya kunjungan di klinik sanitasi yang sebelumnya $1,30 \%$ menjadi $3,88 \%$, melebihi target yang ditetapkan oleh pemerintah yakni sebesar $2 \%$. Evaluasi terus dilakukan melalui pencatatan kunjungan masyrakat ke klinik sanitasi yang disajikan dalam bentuk grafik atau flowchart. Di aspek social, kelompok sosial yang terdampak langsung dari inovasi ini yaitu kelompok masyarakat miskin, kelompok pemuda, kelompok perempuan dan kelompok manula, melalui inovasi Pujasera ini dapat ditingkatkan status sosialnya. Sanitasi yang buruk akibat kemiskinan atau ketiadaan dana dapat diatasi, kelompok perempuan bisa lebih menjaga harkat martabatnya karena mereka dapat BAB dengan lebih menjaga privasi, kelompok pemuda tidak merasa malu apabila ada teman atau relasi yang 
datang karena mereka telah memiliki sanitasi yang baik, serta kelompok manula bisa terhindar dari bahaya seperti hanyut, terpeleset, dan serangan hewan. Keberhasilan tersebuit dapat diukur dari pola hidup masyarakat yang secara sosial menjadi lebih beradab, bermartabat, dan sadar lingkungan.

Adapun pada aspek sumber daya manusia, terjalinnya koordinasi dan sinkronisasi dari seluruh pemangku kepentingan yang terlibat dalam pemicuan inovasi ini. Keberhasilan dapat diukur dari ketersediaan sumber daya manusia yang memadai serta kemudahan dan kelancaran komunikasi atau koordinasi dalam pelaksanaan inovasi di lapangan. Dan untuk aspek lingkungan/ekologis, inovasi Pujasera ini mampu menciptakan lingkungan yang lebih sehat dan bersih, terutama di sepanjang daerah aliran sungai. Ketiadaan feses manusia di sepanjang daerah aliran sungai mampu mengurangi pencemaran air. Keberhasilan tersebut dapat diukur dengan semakin meningkatnya indeks kualitas lingkungan.

Dari program Pujasera ini ada beberapa pelajaran yang dapat dipetik. Di aspek ekonomi, dapat dipetik pelajaran bahwa kemiskinan bukanlah halangan untuk terus meningkatkan standar kesehatan masyarakat, kemiskinan dapat dilawan dengan kreatifitas dan sinergitas. Pada aspek budaya, mengubah perilaku masyarakat, tidak semudah membalikkan telapak tangan, namun jika masyarakat dapat memperbaiki perilakunya dan dapat bekerja sama maka potensi keberhasilan dari program Puajsera dapat ditingkatkan. Melalui inovasi Pujasera dapat dibuktikan bahwa kebiasaan masyarakat yang telah membudaya dapat diubah dengan kerja keras, ketelatenan dan keuletan dalam berusaha, terbukti kebiasaan masyarakat di desa Kaliploso dan Plampangrejo yang sebelumnya buang air besar di sembarang tempat telah berubah menjadi buang air besar di jamban sehingga desa Kaliploso dan Plampangrejo menjadi desa ODF.

Untuk aspek pendidikan, rendahnya tingkat pendidikan masyarakat sekitar memang sangat berpengaruh dalam kelancaran program Puajsera, namun dengan pola komunikasi yang baik dan lebih sederhana, terbukti masyarakat desa Kaliploso dan Plampangrejo dapat bekerjasama dengan baik dalam implementasi inovasi program Pujasera. Pada aspek sumber daya manusia, minimnya sumber daya sanitarian bukanlah menjadi penghalang yang tak bisa diatasi. Pemberdayaan tenaga perawat yang di siapkan sebagai tenaga sanitarian memberikan kemudahan puskesmas untuk melaksankan program kesehatan lingkungan baik yang formal maupun terobosan-terobosan inovasi secara optimal. Disamping itu masyarakat ikut beperan aktif untuk meningkatkan perilaku hidup bersih dan sehat. Kesehatan bukan tanggung jawab petugas kesehatan saja tetapi tanggung 
jawab seluruh masyarakat untuk melindungi dan mengatasi dirinya sendiri terutama kesehatan lingkungan. Sedangkan di aspek sosial, keberhasilan pemberdayaan masyarakat memberikan kepuasan tersendiri bagi tenaga kesehatan dan seluruh pemangku yang terlibat, Sehingga dapat dijadikan spirit untuk menangani masalah-masalah yang lain. Tingkatkan kerja bakti gotong royong membersihkan lingkungan sungai setiap hari Jumat untuk menjaga kelestarian lingkungan sungai dari pencemaran sampah organik dan non organik. Menurut Kementerian Pendayagunaan Aparatur Negara dan Reformasi Birokrasi, program ini cukup istimewa karena sangat mudah diaplikasikan, sehingga inovasi ini bisa diaplikasikan juga oleh daerah lain (www.antarajatim.com). Maka dengan demikian dapat dikatakan bahwa program Pujasera telah mampu merubah pola pikir masyarakat melalui kebutuhan masyarakat itu sendiri.

\section{KESIMPULAN}

Pada tahun 2013 terdapat 27 desa ODF dari 217 desa di Kabupaten Banyuwangi. Namun tak satupun yang berada di wilayah kerja Puskesmas Tampo sehingga dibutuhkan suatu terobosan seperti program "Pujasera". Program Pujasera bermula dari lokakarya lintas sektoral yang diinisiasi oleh Kepala Puskesmas Tampo dengan melibatkan Dinas Kesehatan, Dinas PU Pengairan, Kecamatan Cluring, UPTD
Pendidikan Cluring, PNPM Mandiri, Desa di wilayah kerja Puskesmas Tampo, tokoh agama, toko bangunan, dan stakeholder terkait lainnya. Sosialisasi dilakukan secara aktif dengan menggandeng media Radar Banyuwangi, Radio Airlangga FM, banner dan leaflet yang dipasang ditempat umum dan dibagikan ke masyarakat. Agar program berjalan efektif, selanjutnya dibentuk beberapa tim seperti Kader Pujasera, Satgas ODF, dan 12 kelompok arisan jamban.

Strategi dalam penerapan inovasi Pujasera adalah secara legal formal menerbitkan SK Kapus Tampo No. 440/40/429.114.29/2014, menyusun SOP Pujasera, mengirim tenaga perawat untuk mengikuti pelatihan sanitarian, MoU sosialisasi dengan Radar Banyuwangi dan Radio Airlangga, membuat banner slogan dan ajakan hidup sehat dan leaflet tentang Pujasera, pelatihan kader dengan materi kesehatan lingkungan, MoU dengan UPTD Pendidikan Kecamatan Cluring tentang pembentukan kader Pujasera, pembekalan teknik pengawasan perilaku hidup bersih dan sehat kepada satgas ODF, penandatanganan $\mathrm{MoU}$ dengan PNPM Mandiri Pedesaan dan toko-toko bangunan untuk pemberian pinjaman lunak dana dan material. Mekanisme pinjaman lunak tersebut adalah bahan pembuatan jamban disediakan oleh toko bangunan yang ditunjuk. Jika jamban telah selesai dibangun akan dilaporkan kepada PNPM Mandiri Pedesaan untuk 
dilakukan visitasi sebagai tindak lanjut dari pencairan dana. Arisan jamban ini dilakukan secara rutin setiap bulan terbagi dalam 12 kelompok dimana setiap kelompok terdiri 30 anggota dengan satu kali setoran sebesar Rp 40.000, sehingga penerimaan arisan mendapatkan kucuran dana sebesar Rp. 1.200.000.

Output yang dihasilkan adalah terwujudnya dua desa ODF, meningkatnya kepemilikan jamban sehat, adanya klinik sanitasi, menurunnya angka kesakitan atau morbiditas. Adapun kendala yang muncul antara lain pemicuan tidak dapat dilaksanakan sewaktu-waktu, tidak adanya tenaga sanitasi, masyarakat sulit meninggalkan kebiasaan buang air besar di sungai, dan kemiskinan yang menciptakan stigma bahwa inovasi harus berupa bantuan. Adapun manfaat program Pujasera meliputi perubahan perilaku masyarakat dengan buang air besar di jamban sehat. meningkatnya kesehatan masyarakat, masyarakat miskin dapat lebih mudah memiliki jamban sehat, meningkatkan status sosial masyarakat, dan terjalinnya koordinasi dan sinkronisasi dari seluruh pemangku kepentingan yang terlibat dalam program inovasi Pujasera.

\section{DAFTAR PUSTAKA}

Affandi, Agus et al. 2014. Modul Participatory Action Research (PAR): Untuk Pengorganisasian Mayarakat. Surabaya: LPPM UINSA.
Antara Jatim Online. 2016. Kemenpan RB Apresiasi Arisan Jamban Banyuwangi. Diakses melalui http://www.antarajatim.com pada tanggal 9 Mei 2015.

Common, Richard et al. 1993. Managing Public Services: Competition and Decentralization. $\quad$ Oxford: Butterworth Heinemann.

Departemen Kesehatan Republik Indonesia. 2005. Pembangunan Kesehatan. Jakarta: Pusdatin Depkes RI.

Dunn, William N. 2003. Pengantar Analisis Kebijakan Publik. Yogyakarta: Gadjah Mada University Press.

Dwiyanto, Agus. 2010. Manajemen Pelayanan Publik: Peduli, Inklusif, dan Kolaboratif. Yogyakarta: Gadjah Mada University Press.

Imanuddin, Muhammad. 2016. Inovasi Pelayanan Publik: Percepatan Peningkatan Kualitas Pelayanan Publik. Diakses melalui http://sinovik.menpan.go.id pada tanggal 3 mei 2016.

Kompas Online. 2016. Agar Warga Tak BAB Sembarangan, Arisan Jamban Digelar. Diakses melalui http://www.regional.kompas.co m pada tanggal 9 Mei 2015.

Kusuma, Bayu Mitra A. dan Theresia Octastefani. 2015. "Implementasi Program Jaminan Pelayanan Kesehatan Masyarakat Banyuwangi 
(JPKMB) Dalam Mewujudkan

Pelayanan Kesehatan Primer Bagi Seluruh Lapisan Masyarakat". The Indonesian Journal of Public Administration Vol. 2 No. 1 2015.

Nugroho, Riant. 2014. Public Policy: Teori, Manajemen, Dinamika, Analisis, Konvergensi, dan Kimia Kebijakan. Jakarta: Elex Media Komputindo.

Osborn, Derek et al. 2015. Universal Sustainable Development Goals: Understanding the Transformational Challenge for Developed Countries. London: Stakeholder Forum.

Pemerintah Kabupaten Banyuwangi. 2013. Pemkab Banyuwangi Komitmen, Bidang Kesehatan Jadi Salah Satu Prioritas Pembangunan. Diakses melalui http://www.banyuwangikab.go.i d pada tanggal 2 Mei 2016.

Presiden Republik Indonesia. 2005. Peraturan Presiden RI No. 7 Tahun 2005 tentang Rencana Pembangunan Jangka Menengah Nasional.

Ratminto, R. dan Atik Septi Winarsih. 2006. Manajemen Pelayanan: Pengembangan Model Konseptual, Penerapan Citizen's Charter, dan Standar Pelayanan Minimal. Yogyakarta: Balai Pustaka.

Said, M. Mas'ud. 2012. Birokrasi di Negara Birokratis: Makna,
Masalah dan Dekonstruksi Birokrasi Indonesia. Malang: UMM Press, 2012.

Suryawati, Chriswandani. 2005. "Memahami Kemiskinan Secara Multidimensional". Jurnal Manajemen Pelayanan Kesehatan Vol. 8 No. 32005.

Tangkilisan, Hesel Nogi S. 2003. Kebijakan Publik yang Membumi: Konsep, Strategi, dan Kasus. Yogyakarta: Yayasan Pembaruan Administrasi Publik Indonesia dan Lukman Offset.

Thoha, Miftah. 2012. Birokrasi Pemerintah dan Kekuasaan di Indonesia. Yogyakarta: Thafa Media.

Todaro, Michael P. dan Stephen C. Smith. 2003. Economic Development in the Third World. London: Pearson Education.

United Nations Department of Economics and Social Affairs (UNDESA). 2007. Governance for the Millennium Development Goals: Core Issues and Good Practices. Dipublikasikan di $7^{\text {th }}$ Global Forum on Reinventing Government Building Trust in Government. Wina Austria, 2629 Juni 2007.

Wahab, Solichin Abdul. 2008. Pengantar Analisis Kebijakan Publik. Malang: UMM Press. 
William, F. dan Peter R. Monge. 2011.

Reasoning With Statistic: How

to Read Quantitative Studies.

New York: Harcourt. 